\title{
Kako otroci prvega starostnega obdobja zaznavajo različne jezike?
}

\author{
Anita Sila \\ Univerza na Primorskem \\ anita.sila@pef.upr.si \\ Silva Bratož \\ Univerza na Primorskem \\ silva.bratoz@pef.upr.si
}

Otroci imajo v predšolskem obdobju z izpostavljenostjo tujim jezikom različne izkušnje, ki nedvomno pomembno vplivajo na razvijanje zavedanja tako prvega kot drugih jezikov. Prispevek obravnava zaznavanje in razlikovanje različnih jezikov pri dvo- in triletnih otrocih. $Z$ raziskavo smo želeli ugotoviti, kako se otroci odzivajo na tujejezikovno situacijo, kako zaznavajo prvi in drugi/tuji jezik, na kakšen način izražajo razlikovanje med različnimi jeziki, kako zgodaj že znajo verbalno razlikovati med različnimi jeziki in ali lahko povežejo različne jezike z njihovimi govorci. V ta namen so bili otroci za kratek čas izpostavljeni vnaprej načrtovani situaciji, ki sta jo izvedli raziskovalki v dveh tujih jezikih (angleščina, italijanščina) s štirimi ponovitvami. Rezultati raziskave so pokazali, da lahko že kratkoročna izkušnja otrok s tujimi jeziki pozitivno vpliva na njihovo zaznavanje jezikov in razlikovanje med njimi.

Ključne besede: prvo starostno obdobje, zaznavanje jezikov, razlikovanje jezikov, drugi/tuji jezik, jezikovno zavedanje

\section{Uvod}

Izpostavljenost tujim jezikom je lahko pri otrocih prisotna že $v$ zgodnjem obdobju. Nekateri se z njimi seznanjajo že od rojstva v dvo- ali večjezičnih družinah in dvo- ali večjezičnih okoljih (npr. slovensko zamejstvo), drugi pa prek medijev (npr. televizija, radio, računalnik, telefon ipd.), jezikovnih tečajev in srečanj z ljudmi iz drugih jezikovnih in kulturnih okolij (npr. s priseljenci $v$ vrtcu, na igriščih ipd.). Izkušnje posameznih otrok z izpostavljenostjo drugim/tujim jezikom so različne, a izjemno pomembne za razvijanje zavedanja jezika. Na to kaže tudi primer, ki ga navaja Hakuta (v Marjanovič Umek, Kranjc in Fekonja 2006), v katerem 4-letni dvojezični deček svojemu 5-letnemu angleškemu prijatelju reče: »Jaz znam govoriti francosko in angleško!« Prijatelj, ki je govoril angleško, pa je vprašal: »Kaj je to angleščina?«

Dosedanje raziskave so pokazale, da imajo dvojezični otroci bolje razvito metajezikovno zavedanje kot enojezični, saj se osredotočajo na značilnosti 
dveh jezikov (Yelland, Pollard in Mercuri 1993; Bruck in Genesee 1995; Chen idr. 2004). Dvojezični otroci manipulirajo z jezikovnimi informacijami iz obeh jezikov in tako razvijajo sposobnost metajezikovnega zavedanja ter zavestnega razmišljanja o jeziku. Posledica tega so razvitejše sposobnosti jezikovnega zavedanja v obeh jezikih (Chow, McBride Chang in Burgess 2005). Zaradi izpostavljenosti dvema jezikoma so dvojezični otroci v primerjavi z enojezičnimi sposobni dalj časa zaznavati fonetične razlike med maternim in tujim jezikom (Petitto, Berens in Kovelman 2012). To sposobnost zaznavanja pa ohranijo tudi v odrasli dobi, saj odrasli dvojezični govorci bolje prepoznavajo nove jezike v primerjavi z enojezičnimi (Marks, Bond in Stockmal 2003).

Ravno tako na posameznikovo zaznavanje tujih jezikov tako $v$ otroški kot odrasli dobi vplivajo večjezične izkušnje, kar so potrdile številne raziskave (Marks, Bond in Stockmal 2003; Petitto, Berens in Kovelman 2012). Kljub temu pa dejavniki, ki vplivajo na sposobnost razlikovanja med jeziki pri otrocih, še niso dobro raziskani. Prav tako ni znano, ali lahko že kratkoročne izkušnje izboljšajo zaznavanje tujih jezikov pri otrocih, kot je to značilno za odrasle (Potter in Saffran 2015).

\section{Razvoj govora}

Razvojno obdobje otroka od prvega do tretjega leta otrokove starosti je najobčutljivejše za razvoj govora oziroma simbolnih sistemov, ki vplivajo tako na količinske kot kakovostne spremembe na spoznavnem področju: npr. na odmik mišljenja od zaznavne opore na raven predstavnosti, večjo fleksibilnost in tekočnost mišljenja, tematsko in taksonomsko oblikovanje pojmov ter socialno komunikacijo. Hiter razvoj govora $v$ tem obdobju je povezan z zgodnjim razvojem možganov (Peklaj in Marjanovič Umek 2009). Z ustreznimi spodbudami iz okolja lahko v prvih letih življenja optimalno izkoristimo otrokov umski potencial. Pestriejši in številnejši kot so dražljaji, kompleksnejše strukture se tvorijo. Do drugega leta se število teh povezav oz. sinaps poveča in okrepi, manj uporabljene oz. nerabljene povezave pa slabijo oz. krnijo. Strokovnjaki zato svetujejo, naj pri otroku začnemo čim bolj zgodaj spodbujati različne povezave (Lipavec Oštir in Jazbec 2010). Pozneje je z okoljem povezane primanjkljaje na področju govora zelo težko nadoknaditi (Marjanovič Umek 2001).

Razvijanje govora zahteva mnogostranske izhodiščne pogoje, posebne motorične spretnosti (temeljni predpogoj za govorni razvoj) in kognitivne sposobnosti (da lahko govori in tvori stavke) (Wilken 2012). Otroci se z neverbalnimi signali najprej odzivajo na neugodje oz. zadovoljstvo, nato neverbalne signale pričnejo uporabljati za vzpostavljanje stika z drugo osebo 
in zadovoljevanje želja in potreb, šele nato pričnejo komunicirati z verbalnimi signali, s katerimi so zmožni izraziti različne funkcije $v$ različnih socialnih kontekstih (Marjanovič Umek, Kranjc in Fekonja 2006). Za normalno realizacijo govora je potrebno ustrezno tvoriti posamezne glasove (artikulacija), upoštevati pravila pri besednem redu in stavčni strukturi (skladnja) ter z izgovorjenimi besedami povezati namen (pragmatika) (Wilken 2012). Otroci pri treh letih že poznajo osnovne strategije obvladovanja besedne in nebesedne komunikacije, s katerimi postavljajo vprašanja, nanje odgovarjajo, izražajo mnenja, želje ipd. (Marjanovič Umek, Kranjc in Fekonja 2006).

L. Marjanovič Umek, S. Kranjc in U. Fekonja (2006) na osnovi domačih in tujih raziskav povzemajo značilnosti govornega razvoja, obenem pa opozarjajo, da razvoja otrokovega govora ni mogoče enoznačno umestiti znotraj posameznih mejnikov, saj so med otroci lahko velike individualne razlike.

Komunikacijo pa poleg jezika označujejo tudi drugi načini vedenja in izrazne oblike, s katerimi drugim osebam nekaj sporočamo. Že majhni otroci z jokom in drugo vokalizacijo, s telesno držo, z očesnim stikom, s prijemanjem in kazanjem itd. jasno izražajo svoje potrebe in zanimanje za okolico. Na ta način se čedalje bolje sporazumevajo z osebami, ki so jim pomembne. Vsekakor pa so takšne komunikacijske oblike razumljive le v povezavi s kontekstom in potrebujejo interpretacijo odnosnih oseb, saj te njihova individualna izrazna znamenja razumejo relativno dobro, za druge ljudi pa niso razumljiva (Wilken 2012).

\section{Zgodnje zaznavanje in razlikovanje jezikov}

Med izsledki raziskav, ki so preučevale otrokove prirojene zmožnosti za fonološko učenje, je smiselno omeniti zlasti t. i. kategorialno zaznavanje (ang. categorical perception) glasov, pri katerem gre za dobro zmožnost razlikovanja glasov iz različne fonemske kategorije, in slabšo zmožnost razlikovanja glasov, ki pripadajo isti fonemski kategoriji (Liebenthal idr. 2003). Pri tem je predvsem pomembno to, da so otroci že od rojstva zmožni razlikovati tudi subtilne razlike med akustično podobo glasov, in sicer zlasti med tistimi glasovi, ki so pomembni za jezikovni razvoj (Kuhl 2004). Nekatere raziskave na tem področju (Kuhl 2004) preučujejo prepoznavanje akustične podobe samoglasnikov in ugotavljajo, da so otroci že zelo zgodaj dovzetni za relativne distribucijske frekvence glasovnih segmentov določenega jezika ter da se odzivajo s povezovanjem samoglasniških glasov. Strokovnjaki na tem področju poročajo še, da prihaja $v$ obdobju med 6 . in 12. mesecem do pomembnih sprememb, saj začenjajo otroci $v$ tem obdobju pri zaznavanju glasov dajati prednost prvemu oziroma maternemu jeziku, kar predstavlja enega ključnih 
Preglednica 1 Razvoj govora po mesecih

\begin{tabular}{|c|c|}
\hline Okvirna starost & Značilnosti \\
\hline Novorojenček & $\begin{array}{l}\text { Raje ima človeški glas. } \\
\text { Razlikuje med glasovi. } \\
\text { Razlikuje svoj govor od govora drugih. } \\
\text { Joka. }\end{array}$ \\
\hline 1-5 mesecev & $\begin{array}{l}\text { Razlikuje med samoglasniki. } \\
\text { Gruli. } \\
\text { Vokalizira dva ali več glasov. } \\
\text { Beblja (združuje samoglasnik in soglasnik). } \\
\text { Naredi govorni preobrat. }\end{array}$ \\
\hline 6-12 mesecev & $\begin{array}{l}\text { Čeblja in ponavlja posamezne zloge. } \\
\text { Uporablja geste za komuniciranje. } \\
\text { Razume že več besed. } \\
\text { Izpolni enostavne naloge. } \\
\text { Razlikuje jezik iz svojega okolja od drugega jezika. }\end{array}$ \\
\hline 12-18 mesecev & $\begin{array}{l}\text { Govori enobesedne izjave. } \\
\text { Razume več kot } 50 \text { besed. } \\
\text { Združuje samostalnik in glagol. }\end{array}$ \\
\hline 18-24 mesecev & $\begin{array}{l}\text { Naredi velik skok v razvoju besednjaka. } \\
\text { Začne oblikovati dvobesedne izjave. } \\
\text { Z besedami izraža čustva. } \\
\text { Uporablja telegrafski govor. }\end{array}$ \\
\hline $2,6-5$ let & $\begin{array}{l}\text { Govori večbesedne izjave. } \\
\text { Usvaja nova slovnična pravila. } \\
\text { Oblikuje nikalne in vprašalne izjave. } \\
\text { Besednjak še naprej narašča. } \\
\text { Rad ima humor in metafore. } \\
\text { Kaže napredek v sporazumevalnih spretnostih in drugih oblikah } \\
\text { pragmatične rabe govora. } \\
\text { Govor je razumljiv in tekoč. } \\
\text { Pripoveduje zgodbe. }\end{array}$ \\
\hline $6+$ let & $\begin{array}{l}\text { Kaže metajezikovno zavedanje. } \\
\text { Oblikuje celovite stavke. } \\
\text { Govor uporablja v različnih govornih položajih. }\end{array}$ \\
\hline
\end{tabular}

Opombe Povzeto po Marjanovič Umek, Kranjc in Fekonja (2006).

mejnikov v procesu usvajanja jezika (Kuhl 2007). Pri testiranju 6-mesečnih govorcev ameriške angleščine in švedščine so npr. ugotovili, da so ti dovzetnejši za distribucijske frekvence glasov, ki jih slišijo, in za lažje povezovanje samoglasniških glasov v prvem kot pa v drugem jeziku. Govorimo torej o prehodu od univerzalnega k jezikovno specifičnemu zaznavanju glasov. Gre za t. i. učinek magneta pri samoglasnikih prvega jezika, ki ga npr. pri eksperimentih z opicami niso zaznali, kar kaže na to, da se že v zgodnjem otroštvu razvi- 
jajo zmožnosti za razvoj jezika, ki so edinstvene človeku (Kuhl 1991). Zmožnost ločevanja med različnimi segmenti jezika so na besedni ravni raziskovali tudi J. R. Saffran, Aslin in E. L. Newport (1996) ter prišli do zaključka, da že 8-mesečni otroci razlikujejo med besedami na osnovi verjetnosti povezovanja med zlogi.

Številne raziskave so pokazale, da prične otrok razlikovati med jeziki zelo zgodaj (Karmiloff in Karmiloff-Smith 2001; Kuhl 2004; Werker 1989). Že nekaj dni stari novorojenčki dajejo pri poslušanju prednost maternemu jeziku pred drugimi, čeprav med obema še ne ločijo (Karmiloff in Karmiloff-Smith 2001). Poleg tega lahko ločujejo druge jezike, ki pa morajo biti med seboj dovolj različni, npr. ločujejo lahko med francoščino in ruščino ali med angleščino na eni strani in italijanščino in španščino na drugi (Mehler and Christophe 1994). Novorojenčki so še posebej dovzetni za ritmične lastnosti jezika, saj lahko na podlagi tega npr. francoski otroci razlikujejo med angleščino in japonščino, ki imata različne ritmične lastnosti, ne pa tudi med angleščino in nizozemščino, ki sta v tem pogledu sorodni (Nazzi, Bertoncini in Mehler 1998).

\section{Hipoteza kritičnega obdobja}

Hipoteza o kritičnem obdobju je povezana z eno od najvznemirljivejših dilem na področju tujejezikovnega pouka, in sicer z vprašanjem, ali obstaja kritično obdobje za učenje tujega jezika oz., z drugimi besedami, ali je zgodnejše učenje tujega jezika boljše in učinkovitejše. Gre za vprašanje, ki odraža globalni trend, po katerem se poučevanje tujega jezika pomika vedno nižje po starostni lestvici. Velja namreč splošno prepričanje (Brewster, Ellis in Girard 2002), da bomo določen tuj jezik bolje usvojili, če se ga začnemo učiti v zgodnjem obdobju, kar velja zlasti za usvajanje naravne izgovorjave in naglasa.

Med raziskavami, ki so poskušale dokazati povezavo med zmožnostjo ločevanja glasov v zgodnjem obdobju in uspešnostjo usvajanja tujega jezika, je smiselno omeniti študijo (Kuhl idr. 2005), s katero so ugotovili, da je manjša zmožnost ločevanja glasov tujega jezika povezana z učenjem glasovnih lastnosti prvega jezika. To se je pokazalo $v$ raziskavi, $v$ kateri so testirali jezikovne zmožnosti otrok $v$ različnih obdobjih, najprej pri 7. mesecu, nato pri 14., 18., 24. in 30. mesecu, pri čemer so uporabili standardizirani test percepcije govora na osnovi enostavnih minimalnih parov besed $z$ različnimi samoglasniškimi glasovi (npr. $v$ angleščini tea in two) in pogojevanja (premik glave). Na ta način so dokazovali, da zmožnost ločevanja glasov v zgodnjem obdobju lahko vpliva na njihovo poznejšo sposobnost usvajanja besed, morfologije in skladnje. Pomembno je tudi, da so raziskovalci ločevali med občutljivim in kritičnim obdobjem, pri čemer je za občutljivo obdobje značilno, da 
pride lahko na osnovi pridobljene izkušnje do sprememb v organizmu, medtem ko je kritično obdobje potrebno za določeno učenje, ki ima lahko dolgoročen vpliv. Lennebergova (1967) hipoteza o kritičnem obdobju predpostavlja, da je kritično obdobje za učenje jezika do začetka pubertete (12. leta), ko naj bi se lateralizacija možganov končala. Po tem obdobju naj bi bilo nemogoče popolnoma usvojiti določen jezik. Poznejše študije, npr. Krashnova (1973), so pokazale, da se lateralizacija zaključi veliko prej (pri petih letih) in da to ne predstavlja ovire za učenje tujega jezika po puberteti. Pomen kritičnega obdobja so potrdile npr. raziskave, ki so preučevale dvojezičnost. Kim idr. (1997) so s pomočjo magnetne resonance možganov ugotovili, da so se pri dvojezičnih osebah, ki so to postale v kasnejšem obdobju, v možganih (na področju Broca) aktivirala ločena območja (tj. za slovnico in fonologijo) za oba jezika, medtem ko so se pri osebah z zgodaj razvito dvojezičnostjo ta območja za oba jezika prekrivala.

Čeprav so torej številne raziskave poskušale potrditi prednosti zgodnjega učenja tujega jezika, številni strokovnjaki opozarjajo, da je o dokončnem odgovoru na vprašanje o najboljši starosti za začetek učenja jezika težko govoriti (Brewster idr. 2002; Lightbown in Spada 2006; Pinter 2011). Namesto tovrstnega zaključka je zato smiselneje govoriti o splošnem konsenzu med strokovnjaki, da obstajajo določene prednosti za posamezne starostne skupine. Ena od pomembnejših prednosti zgodnjega začetka učenja tujega jezika je nedvomno $v$ tem, kot smo doslej že omenili, da so otroci dovzetnejši za prepoznavanje in ločevanje glasov tujega jezika, kar lahko pomeni, da bodo $z$ večjo verjetnostjo razvili naravno njegovo izgovorjavo. Ob tem $A$. Pinter (2011) še dodaja, da so mlajši otroci večinoma manj zadržani od odraslih učencev in izražajo nižjo mero tesnobnosti pri učenju tujega jezika, v končni fazi pa z zgodnjim začetkom tudi več časa posvetijo tujejezikovnemu učenju.

Po drugi strani pa lahko govorimo tudi o prednostih učenja jezika v kasnejšem obdobju, $v$ puberteti in odrasli dobi. Birdsong (1992) je npr. prišel do zaključka, da je kljub številnim prednostim zgodnjega začetka z učenjem tujega jezika treba upoštevati, da obstajajo tudi osebe, ki so se jezika začele učiti v odrasli dobi in so kljub temu dosegle raven rojenega govorca. Za razliko od mlajših otrok so starejši učenci zmožni razumeti in analizirati pravila tujega jezika, kar jim omogoči, da razvijejo in uporabijo učinkovite učne strategije česa. Ravno tako se lahko zanesejo na visoko razvito pojmovno strukturo in kognitivne zmožnosti višje ravni (Pinter 2011). Na osnovi zapisanega lahko sklepamo, da je po puberteti težje usvojiti fonološko podobo tujega/drugega jezika, ni pa nemogoče. Pri tem imajo ključno vlogo motivacija, izkušnje, sposobnosti in predanost učenju vsakega posameznika. 


\section{Pomen socialne interakcije za razvoj jezika}

Kot poudarjajo nekatere teorije učenja (npr. Vigotskijeva in Brunerjeva), ima socialna interakcija ključno vlogo pri učenju in razvoju jezika. Bruner (1983, str. 39) npr. poudarja, da »če obstaja mehanizem za usvajanje jezika, potem do njega ne pridemo z izpostavljenostjo 'plohi' govorjenega jezika, temveč predvsem skozi interakcijo, oblikovano s pomočjo podpornega sistema, ki ga pri jezikovnemu usvajanju nudi odrasla oseba.«

P. K. Kuhl, Tsao in H.-M. Liu (2003) ugotavljajo, da so dojenčki, ki so bili izpostavljeni tujemu jeziku v socialnem okolju, bistveno bolje in trajnejše usvojili določene glasove jezika kot dojenčki, ki so bili tujemu jeziku izpostavljeni samo slušno in vizualno (npr. preko televizijskega sprejemnika). Ob tem se P. K. Kuhl (2007) sprašuje, na kakšen način socialna interakcija vpliva na učenje jezika. Ponujata se dva možna odgovora, in sicer najprej delovanje mehanizma pozornosti in spodbud, ki vključuje otrokovo motivacijo. Pozornost in spodbude vplivajo na učenje na različnih področjih, zato se lahko domneva, da bo njihov vpliv na učenje zaznan tudi pri izpostavljenosti novemu jeziku. Drugi razlog gre iskati v pomenu specifičnih informacij v naravnem okolju, ki lahko poleg glasovnega vnosa vključuje številne druge elemente, kot so predmeti, namera in pogled sogovornika ipd. Socialni signali pospešujejo učenje, saj omogočajo z informacijami bogato referenčno okolje (Kuhl 2007). Tomasello (1999, str. 213) poudarja, da kognitivnih procesov seveda ne ustvarja jezik sam; ti se oblikujejo, ko so otroci v intersubjektivni interakciji z drugimi osebami, od katerih prevzamejo komunikacijske norme - ta socialni proces ustvarja novo obliko kognitivne reprezentacije, ki je pri drugih živalskih vrstah ne najdemo.

Učinkovitejše učenje v socialni interakciji pa omogoča tudi čustveni element. Znano je namreč, da čustva občutno vplivajo na procese mišljenja, kot so zaznavanje, učenje, spomin, sklepanje, reševanje problemov, predvsem pa na pozornost. Čustva imajo tudi pomembno vlogo pri usmerjanju naše pozornosti, dejanj in vedenja (Tyng idr. 2017). Posledično pa sta zaradi usmerjene pozornosti boljša tudi učenje in spomin. Slednji je odvisen od konteksta. Dejavnosti, kot so simulacije, igre vlog, sodelovalni projekti, nudijo pomemben kontekstualni okvir, ki pomaga pri priklicu informacij iz spomina v podobnih situacijah v resničnem življenju.

Dosedanje raziskave (Floccia idr. 2009; Potter in Saffran 2015; Stockmal, Muljani in Bond 1994; Wagner, Clopper in Pate 2014), ki so bile usmerjene zlasti v sposobnost razlikovanja med narečnimi jezikovnimi posebnostmi in različnimi jeziki, so bile izvedene na populaciji otrok, starih od 4 do 7 let. Ugotovile 
so, da predvsem mlajši otroci težko razlikujejo med glasovnimi posebnostmi ali narečji določenega jezika. Prav tako imajo težave pri razlikovanju med izjavami v različnih jezikih, saj ne vedo, na katero jezikovno značilnost bi se osredotočili.

$\checkmark$ pričujočem prispevku smo se osredotočili na zaznavanje jezikov pri otrocih v prvem starostnem obdobju (dvo- in triletniki). Predvsem nas je zanimalo, kako bo izpostavljenost malčkov tujejezikovni situaciji, ki vključuje intersubjektivno interakcijo z osebo, ki govori drugi jezik, vplivala na njihovo sposobnost razlikovanja med jeziki, in sicer med prvim/maternim in drugim/tujim jezikom ter med obema drugima/tujima jezikoma. Poleg tega smo želeli ugotoviti, na kakšen način otroci prvega starostnega obdobja izražajo razlikovanje med različnimi jeziki, kako se odzivajo na tujejezikovno situacijo, kako zgodaj že znajo verbalno razlikovati med različnimi jeziki in ali lahko povežejo različne jezike z govorci.

V raziskavi, ki smo jo izvedli z otroki prvega starostnega obdobja, smo izhajali iz predpostavke, da imajo socialni dejavniki ključno vlogo pri zaznavanju tujega jezika, zato smo otroke izpostavili tujemu jeziku v določenem socialnem kontekstu, ki je vključeval predmet in osebo z jasno določeno namero.

\section{Namen raziskave}

Osnovni namen pričujoče raziskave je preučiti, kako 2-3-letniki zaznavajo različne jezike. Zanimalo nas je zlasti, kako pojmujejo razlike med prvim in drugimi jeziki ter kako se odzivajo na izvedbo simuliranega dogodka $v$ angleškem in italijanskem jeziku.

Iskali smo torej odgovore na naslednja vprašanja:

1. Kako se otroci prvega starostnega obdobja odzivajo na simuliran dogodek v tujem jeziku (verbalni in neverbalni odziv, razumevanje)?

2. Kako zaznavajo prvi in drugi/tuji jezik?

3. Na kakšen način izražajo razlikovanje med različnimi jeziki?

4. Kako zgodaj že znajo verbalno razlikovati med različnimi jeziki in ali lahko povežejo različne jezike $z$ njihovimi govorci?

\section{Metodologija}

\section{Opis vzorca}

$\checkmark$ raziskavi je sodelovalo 15 otrok iz treh skupin, od katerih je bila večina (11) enojezičnih, 3 dvojezični in 1 večjezičen. $V$ prvi skupini ( 5 otrok) so bili otroci, stari od 23 do 27 mesecev, v drugi od 25 do 31 mesecev (6 otrok), v tretji pa vsi nad 36 mesecev (4 otroci). 


\section{Pripomočki}

Zbiranje podatkov je potekalo na osnovi opazovalnega lista, ki so ga izpolnile vzgojiteljice (3) sodelujočih otrok, in na osnovi polstrukturiranega intervjuja s posameznimi otroki po zadnji ponovitvi dogodka v obeh jezikih. Na opazovalnem listu so vzgojiteljice beležile verbalni in neverbalni odziv otrok. Verbalni odziv je zajemal izjave in vprašanja otrok o dogodku po končani simulaciji. Neverbalni odziv je zajemal vedenje in čustveni element komuniciranja otrok med in po dogodku. V intervjuju so vzgojiteljice posameznega otroka vprašale, kako sta govorili raziskovalki (pri tem sta si pomagali tudi s fotografijami raziskovalk), ali sta govorili isti jezik, kot ga govorijo otroci in vzgojiteljice v vrtcu, ali sta govorili slovensko, angleško ali italijansko, ali so ju razumeli ter kaj sta raziskovalki hoteli. Odgovore smo analizirali po posameznih vprašanjih glede na starostne skupine otrok in pridobljene rezultate interpretirali v skladu $z$ ugotovitvami raziskav, predstavljenih $v$ teoretičnem delu.

\section{Postopek zbiranja in obdelave podatkov}

Pri raziskavi smo uporabili deskriptivno metodo empiričnega pedagoškega raziskovanja, predvsem kvalitativni pristop. Raziskava je sestavljena iz dveh delov. V prvem delu smo oblikovali dejavnost (iskanje medvedka) s štirimi ponovitvami, namen katere je bil izbrane otroke za kratek čas izpostaviti tujemu/drugemu jeziku. Odločili smo se za dva jezika, in sicer angleščino (ki je v izbranem okolju prvi tuji jezik) in italijanščino ( $k$ i v izbranem dvojezičnem okolju predstavlja drugi jezik oz. jezik okolja). Dejavnost smo nato izvedli v treh skupinah predšolskih otrok v prvem starostnem obdobju (z 2-3-letniki). Dejavnost sta izvedli dve odrasli osebi (raziskovalki), ki sta po načelu »ena oseba en jezik «' vedno govorili samo v angleščini ali samo v italijanščini. Dejavnost, ki sta jo štirikrat ponovili ${ }^{2} v$ dopoldanskem času (po zajtrku $v$ angleščini in pred kosilom v italijanščini), je trajala približno 3 minute. Pred izvedbo dejavnosti sta se raziskovalki z vzgojiteljicami dogovorili, da o izvedeni dejavnosti in uporabljenih jezikih otrokom nič ne razlagajo, saj bi to lahko vplivalo na njihove odgovore. $V$ dogovoru z vzgojiteljicami je raziskovalka (ena je govorila angleški jezik, druga pa italijanskega) vstopila v igralnico, kjer so bili otroci načrtno zbrani pri mizah in v izbranem jeziku pričela iskati medvedka

\footnotetext{
${ }^{1}$ Metoda vezave jezika na osebo (tudi na prostor, čas itd.) je tem priporočljivejša čim nižja je starostna stopnja razvoja otroka (Nećak Lük 1999). V našem primeru je ena vzgojiteljica govorila angleško, druga pa italijansko.

${ }^{2} Z$ dosledno večkratno ponovitvijo dejavnosti smo želeli ustvariti predvidljiv dogodek, ki malčkom omogoča, da se bolje učijo, kar velja tudi za učenje novih besed (Benitez in Saffran 2018).
} 
(ang. teddy bear, it. orsetto), ki ga je vzgojiteljica predhodno postavila na dogovorjeno mesto. Ob tem je neverbalno izražala občutek zaskrbljenosti. Poleg medvedka je vzgojiteljica na drugo dogovorjeno mesto postavila drugo plišasto igračo. Raziskovalka je pri iskanju medvedka najprej prišla do druge igrače in nakazala, da sicer išče igračo, vendar ta še ni bila prava. Nato pa je poiskala svojega medvedka in ko ga je našla, je z navdušenjem večkrat ponovila besedo teddy bear oz. orsetto ter z očesnim stikom usmerila pogled otrok na medvedka. Otrokom je zatem veselo pomahala in brez besed zapustila igralnico. Dogodek sta raziskovalki simulirali še trikrat $v$ treh tednih (vedno obe na isti dan).

\section{Rezultati raziskave in razprava}

Po vsaki izvedbi simuliranega dogodka v dveh tujih jezikih (angleščina, italijanščina) smo najprej poskušali ugotoviti, kako se sodelujoči otroci odzivajo na simulacijo dogodka. Vzgojiteljice so tako med opazovanjem situacije beležile verbalni in neverbalni odziv otrok, ki je podrobneje prikazan v preglednici 2.

Pri prvih dveh skupinah otrok sta vzgojiteljici zabeležili predvsem neverbalni odziv otrok, ki se je po ponovnih obiskih raziskovalk spreminjal. Njihov odziv je bil pri obeh jezikih podoben. Ob izvedbi dogodka so večinoma izražali začudenje in pozitivno presenečenje. Večina otrok je spremljala vsak vzgojiteljičin korak. Z vsako ponovitvijo dogodka so bili otroci veselejši in sproščenejši. Pomen angleške in italijanske besede so razbrali iz konteksta, razumevanje pa so kazali z neverbalnimi signali, kot sta kazanje z roko in očesni stik.

Iz preglednice je razvidno, da se je verbalni odziv z višjo starostjo otrok stopnjeval. Z vsakim nadaljnjim obiskom je vse več otrok medvedka že poimenovalo v izbranem jeziku. Predvidevamo, da je k priklicu besed iz tujih jezikov prispevalo več dejavnikov. Eden od njih je predvidljivost dogodka, saj so malčki z vsakim naslednjim obiskom že predvidevali, kaj bosta raziskovalki iskali. Poleg predvidljivosti pa je k temu prav gotovo pripomogla čustvena obarvanost dogodka. V našem primeru je šlo za simulacijo dogodka, v katerem sta raziskovalki zaskrbljeno iskali medvedka, in sočustvovanje otrok z njima se je pokazalo tudi na njihovih obrazih. Njihov izraz na obrazu se je pozitivno spremenil, ko sta raziskovalki medvedka našli in od navdušenja začeli skakati. Zaradi čustev, ki jih je simulacija v njih vzbudila, menimo, da so si besede $v$ tujem jeziku bolje zapomnili. Nenazadnje pa je k boljši motiviranosti in bolj usmerjeni pozornosti otrok $v$ danih situacijah nedvomno vplivalo tudi to, da so bili otroci postavljeni v intersubjektivno interakcijo z drugimi ose- 
Preglednica 2 Verbalni in neverbalni odziv glede na starost in dogodek $v$ obeh jezikih (angleščina, italijanščina)

\begin{tabular}{|c|c|c|c|c|}
\hline Skupina & $\begin{array}{l}\text { Verbalni odziv - } \\
\text { angleščina }\end{array}$ & $\begin{array}{l}\text { Verbalni odziv - } \\
\text { italijanščina }\end{array}$ & $\begin{array}{l}\text { Neverbalni od- } \\
\text { ziv - angleščina }\end{array}$ & $\begin{array}{l}\text { Neverbalni od- } \\
\text { ziv - italijanščina }\end{array}$ \\
\hline $\begin{array}{l}\text { Prva } \\
\text { skupina } \\
\text { (od } 23 \text { do } 27 \\
\text { mesecev) }\end{array}$ & $\begin{array}{l}\text { Prvo srečanje } \\
\text { En otrok se je z } \\
\text { mrmranjem od- } \\
\text { zval na besedo } \\
\text { teddy bear. }\end{array}$ & $\begin{array}{l}\text { Prvo srečanje } \\
\text { Deklica je zakli- } \\
\text { cala: „Ššš ... po- } \\
\text { slušam!» } \\
\text { Drugo srečanje } \\
\text { Trije otroci so de- } \\
\text { jali: } \\
\text { »u je.» } \\
\text { Ena deklica je za- } \\
\text { klicala: »Orsetto!» }\end{array}$ & $\begin{array}{l}\text { Prvo srečanje } \\
\text { Otroci so bili pre- } \\
\text { senečeni. Eden } \\
\text { od otrok se je na- } \\
\text { smehnil. } \\
\text { Drugo srečanje } \\
\text { Otroci so izražali } \\
\text { veselje in prije- } \\
\text { tno preseneče- } \\
\text { nje. Pomahali so } \\
\text { vzgojiteljici in ji } \\
\text { poslali poljubček. } \\
\text { En otrok je gle- } \\
\text { dal v medvedka } \\
\text { na mizi vsakič, ko } \\
\text { ga je vzgojiteljica } \\
\text { poimenovala. } \\
\text { Tretje srečanje } \\
\text { Dva otroka sta } \\
\text { usmerila pogled k } \\
\text { medvedu na mizi. } \\
\text { Otroci so bili ve- } \\
\text { seli, nasmejani. }\end{array}$ & $\begin{array}{l}\text { Prvo srečanje } \\
\text { Otroci so poslu- } \\
\text { šali in opazovali } \\
\text { vzgojiteljičino } \\
\text { premikanje po } \\
\text { prostoru. Bili so } \\
\text { presenečeni in za- } \\
\text { čudeni. } \\
\text { Drugo srečanje } \\
\text { Vsi otroci so poši- } \\
\text { ljali poljubčke. Bili } \\
\text { so nasmejani, po- } \\
\text { zitivno presene- } \\
\text { čeni. } \\
\text { Tretje srečanje } \\
\text { Otroci so začu- } \\
\text { deno gledali v } \\
\text { vzgojiteljico. En } \\
\text { otrok je pokazal } \\
\text { na medvedka na } \\
\text { mizi. Otroci so bili } \\
\text { veseli, ko jih je } \\
\text { vzgojiteljica poz- } \\
\text { dravila in jim po- } \\
\text { slala poljubček. }\end{array}$ \\
\hline $\begin{array}{l}\text { Druga } \\
\text { skupina } \\
\text { (od } 25 \text { do } 31 \\
\text { mesecev) }\end{array}$ & $\begin{array}{l}\text { Tretje srečanje } \\
\text { En deček je dejal: } \\
\text { »šče berija.» }\end{array}$ & $\begin{array}{l}\text { Drugo srečanje } \\
\text { Deček je dejal: } \\
\text { »šče Orsetto!» } \\
\text { Tretje srečanje } \\
\text { Štirje otroci so za- } \\
\text { klicali: »Orsetto!» }\end{array}$ & $\begin{array}{l}\text { Prvo srečanje } \\
\text { Vsi otroci so bili } \\
\text { začudeni. Strmeli } \\
\text { so in opazovali } \\
\text { vzgojiteljico. } \\
\text { Drugo srečanje } \\
\text { Otroci so prese- } \\
\text { nečeni opazovali } \\
\text { vzgojiteljico. }\end{array}$ & $\begin{array}{l}\text { Prvo srečanje } \\
\text { Vsi otroci so bili } \\
\text { začudeni. Opazo- } \\
\text { vali so vzgojite- } \\
\text { ljico. } \\
\text { Drugo srečanje } \\
\text { Otroci so bili ve- } \\
\text { seli. Opazovali so } \\
\text { vzgojiteljico. }\end{array}$ \\
\hline
\end{tabular}

Nadaljevanje na naslednji strani

bami. Otroci so prepoznavali socialne signale in z raziskovalkama verbalno in neverbalno iskali stik, kot je razvidno iz opisanih primerov. Iz odgovorov smo lahko tudi razbrali, da je eden od otrok celo uporabil novo besedo (kiss) v enem od ciljnih jezikov, da bi z raziskovalko navezal stik. 
Preglednica 2 Nadaljevanje s prejšnje strani

\begin{tabular}{|c|c|c|c|c|}
\hline Skupina & $\begin{array}{l}\text { Verbalni odziv - } \\
\text { angleščina }\end{array}$ & $\begin{array}{l}\text { Verbalni odziv - } \\
\text { italijanščina }\end{array}$ & $\begin{array}{l}\text { Neverbalni od- } \\
\text { ziv - angleščina }\end{array}$ & $\begin{array}{l}\text { Neverbalni od- } \\
\text { ziv - italijanščina }\end{array}$ \\
\hline $\begin{array}{l}\text { Tretja } \\
\text { skupina } \\
\text { (vsi } 36 \\
\text { mesecev } \\
\text { ali več) }\end{array}$ & $\begin{array}{l}\text { Prvo srečanje } \\
\text { Ena deklica je } \\
\text { dejala: »Ona se } \\
\text { smeji, ker je našla } \\
\text { teddy beara.» } \\
\text { Drugo srečanje } \\
\text { Deklica je dejala: } \\
\text { „Tam je teddy } \\
\text { bear, na mizi je.» } \\
\text { Tretje srečanje } \\
\text { Nekaj otrok je kli- } \\
\text { calo »teddy bear«. } \\
\text { Ena deklica je po- } \\
\text { mahala vzgojite- } \\
\text { ljici in rekla: »Kiss } \\
\text { kiss«. }\end{array}$ & $\begin{array}{l}\text { Prvo srečanje } \\
\text { Ena deklica je de- } \\
\text { jal: »Je šla ven, } \\
\text { ko je našla med- } \\
\text { vedka orsota.« } \\
\text { Ena deklica je de- } \\
\text { jala: »Je iskala } \\
\text { medvedka. Tam } \\
\text { na mizi je bil. Na } \\
\text { koncu je klicala } \\
\text { orsetto, orsetto!« } \\
\text { Drugo srečanje } \\
\text { Ena od deklic je } \\
\text { po koncu do- } \\
\text { godka klicala »or- } \\
\text { setto.« } \\
\text { Tretje srečanje } \\
\text { Otroci so dogo- } \\
\text { dek opazovali in } \\
\text { potiho ponavljali } \\
\text { »orsetto«. }\end{array}$ & $\begin{array}{l}\text { Prvo srečanje } \\
\text { Otroci so dogo- } \\
\text { dek opazovali v } \\
\text { tišini za mizo. Bili } \\
\text { so veseli in spro- } \\
\text { ščeni. En deček } \\
\text { dogodka in osebe } \\
\text { sploh ni zaznal. } \\
\text { Drugo srečanje } \\
\text { Otroci so s pr- } \\
\text { stom pokazali, } \\
\text { kje je medved, } \\
\text { in se med seboj } \\
\text { spogledovali. Bili } \\
\text { so veseli in spro- } \\
\text { ščeni. } \\
\text { Tretje srečanje } \\
\text { Otroci so dogo- } \\
\text { dek veselo opa- } \\
\text { zovali, se sme- } \\
\text { jali in spogledo- } \\
\text { vali. Očesno so } \\
\text { spremljali vzgo- } \\
\text { jiteljico. Vzgojite- } \\
\text { ljici so pomahali v } \\
\text { pozdrav. }\end{array}$ & $\begin{array}{l}\text { Prvo srečanje } \\
\text { Otroci so spre- } \\
\text { mljali vzgojiteljico } \\
\text { med iskanjem } \\
\text { medvedka. Spre- } \\
\text { mljali so jo z ve- } \\
\text { čjim zanimanjem } \\
\text { kot vzgojiteljico } \\
\text { zjutraj. Otroci so } \\
\text { bili veseli in še } \\
\text { bolj sproščeni. } \\
\text { Drugo srečanje } \\
\text { Ena od deklic je } \\
\text { pokazala s prstom } \\
\text { na drugo plišasto } \\
\text { igračo (kuža). } \\
\text { Druga deklica pa } \\
\text { je s prstom poka- } \\
\text { zala na mizo, kjer } \\
\text { se je nahajal med- } \\
\text { vedek. Otroci so } \\
\text { bili veseli. } \\
\text { Tretje srečanje } \\
\text { Otroci so veseli } \\
\text { očesno spremljali } \\
\text { vzgojiteljico. }\end{array}$ \\
\hline
\end{tabular}

Nadalje nas je zanimalo, kako otroci zaznavajo druge jezike. Vzgojiteljice so z vsakim otrokom posebej izvedle intervju, v katerem so jih spraševale o tem, kako sta govorili raziskovalki, ali sta govorili isti jezik, kot ga govorijo otroci in vzgojiteljice v vrtcu, ali sta govorili slovensko, angleško ali italijansko, ali so ju razumeli ter kaj sta raziskovalki hoteli.

V prvi skupini verbalnega odziva pri izvedbi intervjuja ni bilo. Otroci so bili ob vprašanjih začudeni in niso želeli sodelovati. Zaradi majhnega števila v raziskavi udeleženih otrok težko sklepamo, ali je enojezičnost/dvojezičnost otrok vplivala na njihove odgovore o jeziku raziskovalk. Glede na to, da sta samo dva triletna otroka od vseh udeleženih skušala raziskovalki povezati $z$ različnima jezikoma, ocenjujemo, da otroci te starosti zaradi pomanjkanja izkušenj v teh jezikih težko poimenujejo jezik raziskovalk. Otroci so zaznali, da sta raziskovalki govorili različna jezika (različna med seboj in drugačna od 
Preglednica 3 Odgovori otrok glede na posamezna vprašanja in starostno skupino

\begin{tabular}{|c|c|c|}
\hline Vprašanja & $\begin{array}{l}\text { Druga skupina } \\
\text { ( } 6 \text { otrok, starih od } 25 \text { do } 31 \\
\text { mesecev, } 1 \text { od teh } \\
\text { dvojezičen) }\end{array}$ & $\begin{array}{l}\text { Tretja skupina } \\
\text { ( } 4 \text { enojezični otroci, stari } 36 \\
\text { mesecev ali več) }\end{array}$ \\
\hline Kako je govorila vzgojiteljica A? & Ni odgovora. (6) & $\begin{array}{l}\text { Teddy bear (3) } \\
\text { Medvedka, teddy bear. (1) }\end{array}$ \\
\hline Kako je govorila vzgojiteljica B? & $\begin{array}{l}\text { Orsetto. (1) } \\
\text { Ni odgovora. (5) }\end{array}$ & $\begin{array}{l}\text { Orsetto. (2) } \\
\text { Orso. (1) } \\
\text { Ni odgovora. (1) }\end{array}$ \\
\hline $\begin{array}{l}\text { Ali govorita vzgojiteljici A in B } \\
\text { isti jezik kot mi v vrtcu? }\end{array}$ & $\begin{array}{l}\text { Ja. (5) } \\
\text { Ne. (1) }\end{array}$ & $\begin{array}{l}\text { Ne. (3) } \\
\text { Ne vem. (1) }\end{array}$ \\
\hline $\begin{array}{l}\text { Kako govorita vzgojiteljici - } \\
\text { slovensko, angleško, italijansko? }\end{array}$ & $\begin{array}{l}\text { Slovensko. (1) } \\
\text { Italijansko. (1 - dvojezičen } \\
\text { otrok) } \\
\text { Ni odgovora. (4) }\end{array}$ & $\begin{array}{l}\text { Slovensko in italijansko. (1) } \\
\text { Angleško in italijansko. (1) } \\
\text { Ne vem. (1) } \\
\text { Teddy bear, orsetto. (1) }\end{array}$ \\
\hline Ali si jih razumel/a? & $\begin{array}{l}\text { Ja. (4) } \\
\text { Ne. (1 - dvojezičen otrok) } \\
\text { Ni odgovora. (1) }\end{array}$ & $\begin{array}{l}\text { Ja. (3) } \\
\text { Kaj. (1) }\end{array}$ \\
\hline Kaj je hotela vzgojiteljica A? & $\begin{array}{l}\text { Orsetto. (1) } \\
\text { Tukaj. (1 - dvojezičen otrok) } \\
\text { Ni odgovora. (4) }\end{array}$ & $\begin{array}{l}\text { Medvedka. (1) } \\
\text { Medveda. (1) } \\
\text { Teddy bear. (1) } \\
\text { Teddy beara. (1) }\end{array}$ \\
\hline Kaj je hotela vzgojiteljica B? & Ni odgovora. (6) & $\begin{array}{l}\text { Tudi medvedka. (2) } \\
\text { Medveda. (1) } \\
\text { Iskala je medeka, klicala je } \\
\text { orsetto. (1). }\end{array}$ \\
\hline
\end{tabular}

maternega), vendar so imeli težave pri povezovanju, da je beseda »orsetto« italijanska, beseda »teddy bear« pa angleška ter, posledično, da je ena raziskovalka govorila angleško, druga pa italijansko. Da bi preverili njihovo razumevanje, smo jih vprašali, kaj sta raziskovalki želeli. Iz odgovorov lahko sklepamo, da so tujo besedo zagotovo razumeli otroci, stari 36 mesecev in več, saj so jo tudi jasno povedali, medtem ko lahko o razumevanju tujih besed pri posameznih mlajših otrocih le ugibamo, saj je bil njihov verbalni odziv v intervjuju bolj skop. Samo en otrok iz druge skupine je povedal, da je raziskovalka, ki je govorila angleško, želela »orsetto«. V tem primeru je pri raziskovalki, ki je govorila angleško, povedal italijansko besedo. Kljub skopemu verbalnemu odzivu v intervjuju ne moremo reči, da razumevanja besed ni bilo, saj je iz verbalnega odziva v preglednici 2 razvidno, da so kar štirje otroci zaklicali »orsetto«, ko ga je vzgojiteljica (raziskovalka) iskala. V nekaterih zgoraj predstavljenih primerih lahko opazimo tudi interference iz slovenskega jezika, in 
sicer pri sklanjanju besede teddy bear (npr. hotela je teddy beara; išče berija; je našla orsota). $V$ enem primeru pa takšnega negativnega transferja ni bilo (npr. v otrokovi izjavi »išče orsetto«). Predvidevamo, da gre za nezavedno izbiro besed, saj ti otroci obeh jezikov ne poznajo dovolj dobro, da bi se lahko za njihovo (ne)sklanjanje zavestno odločali.

Teden dni po izvajanju dejavnosti so vzgojiteljice $v$ pogovoru $z$ raziskovalko navedle tudi svoja opažanja iz vsakdanje prakse o tem, kako otroci zaznavajo jezike. Dejale so, da se nekateri otroci na tujejezikovno situacijo niso odzvali takoj, temveč šele čez kakšen teden. Ugotovile so, da otroci, ki doma govorijo več jezikov, prej zaznajo tuj jezik in se nanj tudi prej odzovejo. Ena od vzgojiteljic je omenila, da je otrok iz prve starostne skupine, $v$ kateri nismo zabeležili verbalnega odziva po simuliranih dogodkih, po enem tednu v stranišču iskal medvedka in govoril: »Kje je beri?« Prav tako so ob kasnejšem, nenačrtovanem obisku raziskovalke, ki je med raziskavo govorila v italijanščini, otroci samostojno pričeli klicati »orsetto«. To smo zaznali tudi v intervjujih, ko so otroci raziskovalko, ki je govorila angleško, prav tako povezali z besedo »teddy bear«, raziskovalko, ki je govorila italijansko, pa z besedo »orsetto«. Iz njihovih odgovorov je razvidno, da se je izvedba dejavnosti po načelu »ena oseba en jezik« pri otrocih te starosti obrestovala.

Pri najstarejših otrocih smo opazili tudi, da so v intervjujih uporabili oba izraza (medvedek in teddy bear ali medvedek in orsetto), kar pri tej starosti ne preseneča, saj tudi dvojezični otroci v obdobju od treh do štirih let razlikujejo med dvema različnima besednjakoma, vendar pa $v$ obeh jezikih uporabljajo enaka slovnična pravila (kot smo videli v primeru interferenc). $V$ tem obdobju so otroci sposobni prevajati en jezik v drugega, tisti otroci, ki so dvojezični, pa se svoje dvojezičnosti tudi zavedajo (Marjanovič Umek, Kranjc in Fekonja 2006). Iz vsega opisanega lahko sklenemo (tako kot sta ugotovila tudi $C$. E. Potter in J. R. Saffran 2015), da že kratkoročna zgodnja izpostavljenost več jezikom $v$ okolju lahko vpliva na otrokovo zaznavanje in razlikovanje tujih jezikov.

\section{Zaključek}

Z raziskavo smo želeli ugotoviti, kako se malčki odzivajo na simuliran dogodek v dveh tujih jezikih (angleščina, italijanščina), kako zaznavajo prvi in drugi/tuji jezik, na kakšen način izražajo razlikovanje med različnimi jeziki, kako zgodaj že znajo verbalno razlikovati med različnimi jeziki in ali lahko povežejo različne jezike $z$ njihovimi govorci. Rezultati opravljene raziskave so pokazali, da se otroci v tem starostnem obdobju na tujejezikovno situacijo odzivajo tako verbalno kot neverbalno. Neverbalni odziv je vključeval pred- 
vsem strmenje, začudeno opazovanje, smehljanje, navdušenje, usmerjanje pogleda, kazanje z roko na medvedka in pošiljanje poljubčkov. Starejši kot so bili otroci, več je bilo verbalnega odziva. $Z$ vsakim nadaljnjim obiskom je vse več otrok medvedka že poimenovalo $v$ izbranem jeziku, $k$ čemur je nedvomno pripomogla predvidljivost situacije, poleg tega pa tudi čustvena obarvanost dejavnosti in intersubjektivna interakcija z raziskovalkama. Nadalje so rezultati pokazali, da so predvsem starejši otroci iz prvega starostnega obdobja besedo »teddy bear « povezali z raziskovalko, ki je govorila v angleškem jeziku, besedo »orsetto « pa z raziskovalko, ki je govorila v italijanskem jeziku, kar je bil tudi namen izvajanja situacije po načelu »ena oseba, en jezik«. Zaznali so tudi, da sta raziskovalki govorili različna jezika (različna med seboj in drugačna od maternega), vendar so imeli težave pri poimenovanju jezika, kar kaže na kompleksnost razumevanja pojma jezika v tem obdobju. Z raziskavo smo želeli osvetliti pomen vključevanja različnih jezikov v okolje otrok že v zgodnjem obdobju, saj lahko že kratkoročne izkušnje z novim jezikom vplivajo na otrokovo zaznavanje in razlikovanje tujih jezikov. V prihodnje bi bilo smiselno na tem področju preučevati tudi vpliv drugih dejavnikov na jezikovno zaznavanje, zlasti upoštevajoč značilnosti dvojezičnih in večjezičnih okolij, iz katerih otroci prihajajo.

\section{Literatura}

Benitez, V., in J. R. Saffran. 2018. »Predictable Events Enhance Word Learning in Toddlers." Current Biology 28 (17): 2787-2793.

Birdsong, D. 1992. »Ultimate Attainment in Second Language Acquisition. Language 68 (4): 706-755.

Brewster, J., G. Ellis, in D. Girard. 2002. The Primary English Teacher's Guide. Harlow: Longman.

Bruck, M., in F. Genesee. 1995. »Phonological Awareness in Young Second Language Learners." Journal of Child Language 22 (2): 307-324.

Bruner, J. 1985. „Child's Talk: Learning to Use Language.« Child Language Teaching and Therapy 1 (1): 111-114.

Chen, X., R. C. Anderson, W. Li, M. Hao, X. Wu in H. Shu. (2004). »Phonological Awareness of Bilingual and Monolingual Chinese Children. « Journal of Educational Psychology 96 (1): 142-151.

Chow, B. W. Y., C. McBride Chang in S. Burgess. 2005. »Phonological Processing Skills and Early Reading Abilities in Hong Kong Chinese Kindergarteners Learning to Read English as a Second Language." Journal of Educational Psychology 97 (1): 81-87.

Floccia, C., J. Butler, F. Girard, and J. Goslin. 2009. „Categorization of Regional and Foreign Accent in 5- to 7-Year-Old British Children.« International Journal of Behavioral Development 33:366-375. 
Karmiloff, K., in A. Karmiloff-Smith. 2001. Pathways to Language. Cambridge, MA: Harvard University Press.

Kim, K. H., N. R. Relkin, K. M. Lee, in J. Hirsch. 1997. »Distinct Cortical Areas Associated with Native and Second Languages. N Nature 388 (6638): 171-174.

Krashen, S. D. 1973. »Lateralization, Language Learning, and the Critical Period: Some New Evidence."Language Learning 23:63-74.

Kuhl, P. K. 1991. »Human Adults and Human Infants Show a 'Perceptual Magnet Effect' for the Prototypes of Speech Categories, Monkeys do Not.«Perception \& Psychophysics 50:93-107.

- 2004. »Early Language Acquisition: Cracking the Speech Code.« Nature Reviews Neuroscience 5 (11), 831-843.

_. 2007. »/s Speech Learning 'Gated' by the Social Brain?« Developmental Science 10 (1): 110-120.

Kuhl, P. K., B. T. Conboy, D. Padden, T. Nelson in J. Pruitt. 2005. „Early Speech Perception and Later Language Development: Implications for the Critical Period. « Language Learning and Development 1 (3-4): 237-264.

Kuhl, P. K., F.-M. Tsao, and H.-M. Liu. (2003). »Foreign-Language Experience in Infancy.«Proceedings of the National Academy of Sciences 100:9096-9101.

Lenneberg, E. 1967. Biological Foundations of Language. New York: Wiley.

Liebenthal, E., J. R. Binder, S. M. Spitzer, E. T. Possing in D. A. Medler. 2003. »Neural Correlates of Categorical Perception of Speech.«https://pdfs .semanticscholar.org/145f/f8a373aoc2906de28a097afcc7bb644bc41a.pdf

Lightbown, P. M., N. Spada, L. Ranta in J. Rand. 2006. How Languages are Learned. Oxford: Oxford University press.

Lipavic Oštir, A., in S. Jazbec. 2010. »Zgodnje učenje tujega jezika z vidika nekih teorij.«https://www.zrss.si/projektiess/skladisce/sporazumevanje_v_tujih _jezikih/tuj-jezik-v-prvem-triletju/Strokovni\%20\%C4\%8Dlanki\%2oin \%2oprevodi/zgodnje_ucenje_tujega_jezika_z_vidika_razlicnih_teorij _lipavic_ostir.pdf

Marjanovič Umek, L. 2001. »Psihologija predšolskega otroka.« V Otrok v vrtcu: priročnik h kurikulu za vrtce, ur. L. Marjanovič Umek, 26-54. Maribor: Obzorja.

Marjanovič Umek, L., S. Kranjc in U. Fekonja. 2006. Otroški govor: razvoj in učenje. Domžale: Izolit.

Marks E. A., Z. S. Bond in V. Stockmal. 2003. "Language Experience and the Representation of Phonology in an Unknown Language." RESLA 16:23-31.

Mehler, J., in A. Christophe. 1994. »Language in the Infant's Mind.«Philosophical Transactions of the Royal Society of London, Series B - Biological Sciences, 346 (1315): 13-20.

Nazzi T., J. Bertoncini in J. Mehler. 1998. »Language Discrimination by Newborns: Toward an Understanding of the Role of Rhythm. «ournal of Experimental Psychology: Human Perception and Performance 24:756-766. 
Nećak Lük, A. 1999. »Modeli izobraževanja v etnično in jezikovno heterogenih okoljih: analiza strukturnih elementov za izbiro modelov izobraževanja v slovenskem etničnem prostoru.« Raziskovalno poročilo, Filozofska fakulteta, Ljubljana.

Fekonja Peklaj U. in Marjanovič Umek L. 2009. "Socialni konteksti in ocenjevanje govorne kompetentnosti malčkov in malčic." Sodobna pedagogika 3:18-39.

Petitto L., M. Berens in I. Kovelman. 2012. »The 'Perceptual Wedge' Hypothesis as the Basis for Bilingual Babies' Phonetic Processing Advantage: New Insights from fNIRS Brain Imaging."Brain and Language 121:130-143.

Pinter, A. 2011. Children Learning Second Languages. Houndmills: Palgrave Macmillan.

Potter, C. E., in J. R. Saffran. 2015. »The Role of Experience in Children's Discrimination of Unfamiliar Languages. « Frontiers in Psychology 6:1587. https://www.doi.org/10.3389/fpsyg.2015.01587

Saffran, J. R., R. N. Aslin in E. L. Newport. 1996. "Statistical Learning by 8-Month Old Infants.« Science 274:1926-1928.

Stockmal, V., D. Muljani in Z. Bond. 1994. »Can Children Identify Samples of Foreign Languages as Same or Different?« Language Sciences 16:237-252.

Tomasello, M. 2009. The Cultural Origins of Human Cognition. Cambridge, MA: Harvard University Press.

Tyng, C. M., H. U. Amin, M. N. M. Saad in A. S. Malik. 2017. »The Influences of Emotion on Learning and Memory. «Frontiers in Psychology 8:1454.

Wagner L., C. G. Clopper in J. K. Pate. 2014. »Children's Perception of Dialect Variation." Journal of Child Language 41:1062-1084.

Werker, J. F. 1989. »Becoming a Native Listener.« American Scientist 77:349-353.

Wilken, E. 2012. Jezikovno spodbujanje otrok z Downovim sindromom. Ljubljana: Pedagoška fakulteta.

Yelland, G., J. Pollard in A. Mercuri. 1993. »The Metalinguistic Benefits of Limited Contact with a Second Language. «Applied Psycholinguistics 14 (4): 423444.

\section{How Are Different Languages Perceived by Children in the First Age Group?}

The extent to which pre-school children are exposed to second languages may vary considerably and their experiences in this period have a significant impact on the development of language awareness. The present paper investigates the different ways in which two and three year old children perceive first and second languages and distinguish between them. The research presented was aimed at analysing the participants' reaction to a foreign language situation and identifying the ways in which they express the distinction between different languages. In addition, the study focused on analysing the time the 
children start differentiating between languages verbally and exploring the ways in which they associate a particular language with the speaker of that language. To this purpose, children who participated in the research were exposed to two foreign language situations created by two researchers in two languages (English and Italian), each repeated four times. The results of the research suggest that even short-term exposures may have a positive impact on the children's perception of different languages and the distinctions between. Keywords: two/three year old children, language awareness, language differentiation, language perception, second/foreign languages 